\title{
PENGARUH KOMPOS LIMBAH KULIT NANGKA (Artocarpus heterophyllus) DENGAN METODE TAKAKURA TERHADAP PERTUMBUHAN DAN PRODUKTIVITAS TANAMAN TOMAT CERI (Lycopesicum esculantum Mill)
}

\author{
Wisnu Rahmatullah ${ }^{1 *}$, Yuni Krisnawati ${ }^{2}$, Yunita Wardianti ${ }^{3}$ \\ 1,2,3 STKIP PGRI Lubuklinggau, Jl. Mayor Toha Kel. Air Kuti, Lubuklinggau 31626, Indonesia \\ *Corresponding author, e-mail: wisnurahmatullah34@gmail.com
}

\begin{abstract}
This study aims to determine the effect of jackfruit skin compost fertilizer (Artocarpus heterophyllus) with the takakura method on the growth and productivity of the cherry tomatoes (Lycopersicum esculentum Mill) plant. The study was conducted at the STKIPPGRI Biology Garden in Lubuklinggau. Using a completely randomized design (CRD) with 6 treatments and 4 repetitions, namely P0 + (NPK), P0- (growing media), P1 (318 grams), P2 (381 grams), P3 (445 grams) and P4 (509 grams). The research parameters in the form of growth parameters include plant height and number of leaves, productivity parameters include the number of flowers, the number of fruit plants and the weight of fruit plants. Data collection techniques using observation sheets and analyzed with Anova. Compost fertilizer had no effect on the observation of plant height of $\mathrm{Fe} 1.83<\mathrm{Ft}$ 2.77 , on observing the number of flowers Fe $0.43<\mathrm{Ft} 2.77$, on observing the number of fruit $\mathrm{Fe} 2.21<\mathrm{Ft} \mathrm{2.77.} \mathrm{On} \mathrm{the} \mathrm{parameters} \mathrm{of} \mathrm{the} \mathrm{number} \mathrm{of} \mathrm{leaves} \mathrm{the} \mathrm{data} \mathrm{obtained} \mathrm{were}$ significant Fe 3.04> Ft 2.77, the weight of the data obtained was significant Fe 4.88> Ft 2.77. It can be concluded that jackfruit skin waste compost with takakura method has no effect on the height, number of flowers and the number of cherry tomato plants, but has an influence on the number of leaves and the weight of the fruit planted.
\end{abstract}

Keywords: Compost, Takakura, Jackfruit Skin, Cherry Tomatoes

\section{PENDAHULUAN}

Lubuklinggau merupakan kota transit yang menghubungkan antara provinsi Jambi dan Bengkulu, yang menjadikan Lubuklinggau menjadi sebagai kota transit dan kota yang sedang berkembang pesat. Semakin Pesatnya pembangunan yang digalakan pemerintah maka populasi juga semakin meningkat, yang akan berdampak pada masyarakat yang semakin konsumtif. Sama seperti kota yang sedang berkembang lainnya masalah yang sering muncul adalah sampah perkotaan dalam satu hari saja Kota Lubuklinggau bisa menghasilkan 16 ton sampah (Mauli, 2017). Hal ini bisa disebabkan karena kurangnya kesadaran masyarakat akan dampak yang ditumbulkan sampah dan juga karena kurangnya pengetahuan masyarakat megenai pengolahan sampah.

Sampah pasar merupakan salah satu sektor penyumbang tersebar sampah yang ada di Kota Lubuklinggau, walaupun sudah disediakan bak penampung sampah namun masyarakat tetap membuang sampah secara sembarangan. Hal ini akan berdampak pada menurunnya keindahan kota dan juga akan menyebabkan polusi bagi lingkungan yang bisa berdampak pada gangguan kesehatan (Warsidi, 2010). Salah satu sampah yang ikut berserakan adalah sampah kulit nangka, berdasarkan hasil observasi dan wawancara pada tangggal 18 November 2018 para penjual bisa menjual 2 sampai 3 buah nangka dalam satu hari untuk memenuhi kebutuhan 
warung nasi yang ada di Kota Lubuklinggau, sedangkan kulitnya akan dibiarkan menumpuk dengan sampah lainnya. pengambilan sampah kulit nangka, dari setiap penjual nangka bisa menghasilkan 5 karung limbah kulit nangka dalam satu harinya.

Selama ini masayarakat pada umumnya hanya memenafaatkan daging buah nangka dan biji nangka saja baik dikonsumsi secara langsung maupun dijadikan sebagai lauk nangka sedangkan biji nangka bisa direbus unntuk dijadikan sebagai cemilan dan kulit nangka hanya dibuang begit saja tanpa diolah terlebih dahulu. Sejatinya limbah kulit nangka merupakan sampah organik yang bisa dijadikan bahan baku kompos, menurut Kurniawan dkk (2014) limbah kulit nangka mengandung serat kasar, protein, glukosa, fruktosa, sukrosa, pati, serat, pektin, karbon dan nitrogen yang dapat dimanfaatkan sebagai pupuk dan berfungsi untuk pertumbuhan dan perkembangan tanaman. Kandungan karbon yang ada didalam kulit nangka merupakan unsur hara makro yang dibutuhkan oleh tanaman yang berfungsi untuk meningkatkan pertumbuhan tanaman dan juga dapat mempercepat pemasakan buah (Tim Bina Karya Tani, 2013). Keadaan kondisi lahan yang sempit seperti Kota Lubuklinggau maka pengomposan dengan teknik takakura bisa menjadi solusinya karena melihat dari beberapa kelebihan pengomposan takakura bersih, praktis dan tidak berbau, (Hidayah, 2017).

Kondisi lahan yang sempit akan membuat masyarakat berbudidaya tanaman melalui pot dan tentunya tanaman didalam pot akan memerlukan unsur hara yang cukup untuk menunjang pertumbuhannya. Untuk mencukupi unsur hara tanaman didalam pot tentunya didapkan melalui proses pemupukan. Penggunaan pupuk kompos menjadi cara yang baik untuk mendapatkan hasil produktivitas yang maksimal dan sehat hal ini karena pupuk kompos memiliki keunggulan dibandingkan yaitu dapat membuat tanaman tumbuh lebih baik, dapat memperbaiki struktur tanah (Warsidi 2010) dan juga dapat meningkatkan nilai jual dari bahan baku sampah itu sendiri. Pupuk kompos bagaikan sumber multivitamin bagi tanaman dan membantuk tanaman dalam menghadapi serangan hama dan penyakit (Isroi, 2009).

Salah satu tanaman yang banyak digemari masyarakat pada umumnya adalah tanaman tomat dan termasuk tanaman yang dapat dibudidaya didalam pot. Tanaman tomat memiliki banyak varietas salah satunya yaitu varietas tomat ceri. Tomat ceri memiliki buah yang berukuran kecil-kecil dengan rasa asam yang sedikit manis sehingga memberikan sensasi segar ketika mengkonsumsinya. Tomat ceri juga bisa diolah menjadi berbagi macam olahan makanan sehingga tuntutan akan ketersedian tomat ceri juga akan semakin meningkat, oleh karena itu perlu dilakukan peningkatan produktivitas budidaya tomat ceri dengan mengaplikasikan pupuk kompos limbah kulit nangka dengan metode takakura pada budidaya tonaman tomat ceri.

\section{METODE}

Penelitian ini dilaksanakan di kebun Biologi STKIP PGRI Lubuklinggau. Waktu penelitian dilaksanakan dari bulan April sampai bulan Juli 2019. Bahan-bahan yang digunakan dalam penelitian ini adalah sebagai berikut: limbah kulit nangka, kotoran ayam yang telah matang (dengan ciri-ciri berwarna coklat tua hingga hitam, tidak berbau, teksturnya menyerupai tanah, dan tidak panas), limbah serbuk kayu, EM4, bibit tomat ceri, tanah dan air. Alat yang digunakan dalam penelitian ini adalah yaitu, polybag ukuran $5 \mathrm{Kg}$, sendok semen, keranjang berlubang, kain berpori, kardus, sekam (serbuk kayu), kamera, label nama, sepidol hitam permanen, lakban 
transparan, penggaris, sprey, kayu, tali plastik, timbangan dan pengukur abiotik termometer dan soil tester.

Limbah kulit nangka yang telah dikumpulkan dicuci bersih untuk menghilangkan getahnya kemudian dipotong kecil-kecil. Kemudian limbah kulit nangka yang sudah dipotong dicampur dengan kotoran sapi dengan perbandingan 1:1 kemudian campurkan $85 \mathrm{ml}$ EM4 lalu aduk hingga rata. Siapkan keranjang kemudian tutup seluruh isinya menggunakan kardus. Buatlah dua bantalan sekam yang menyesuaikan dengan luas dari keranjang yang digunakan, bantalan sekam terbuat dari kain berpori yang didalamnya dimasukan sekam lalu ujung-ujungnya diikat dengan kuat. Letakan satu bantalan sekam pada dasar keranjang dan dan satunya disimpan sebagai penutup. Lalu masukan bahan baku pengomposan kedalam keranjang dan tutup menggunakan bantalan sekam pada bagian atasnya (Hidayah, 2017).

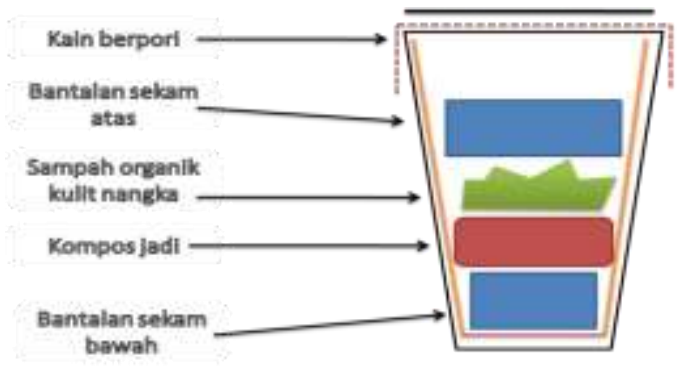

Gambar 1. Gambaran Pengomposan Takakura

Pemupukan dilakukan sebanyak 4 kali dengan interval waktu 2 minggu sekali. Pemupukan dilakukan sebelum masa generatif (8 minggu) tanaman karena pemupukan pada masa ini dianggap kurang efektif. Tersedianya unsur hara yang cukup pada masa vegatatif dapat membantu perkembangan tomat pada masa generatif (Zabarti dkk, 2010). Parameter yang diamati yaitu parameter pertumbuhan (tinggi tanaman dan jumlah daun), dan parameter produktivitas (jumlah bunga, jumlah buah, dan berat buah). Metode yang digunakan dalam penelitian ini adalah metode eksperimen murni dengan menggunakan desain RAL dengan 6 kelompok perlakuan dan 4 pengulangan yang didapatkan melalui persamaan Federer, sebagai berikut:

$$
(\mathrm{t}-1)(\mathrm{r}-1) \geq 15
$$

$$
\begin{aligned}
\text { Keterangan: } & t=\text { jumlah perlakuan } \\
r & =\text { jumlah pengulangan }
\end{aligned}
$$

Tabel 1. Perlakuan Pupuk Kompos

\begin{tabular}{cc}
\hline Perlakuan & Dosis \\
\hline $\mathrm{P}^{+}$ & (NPK) 10 gram \\
$\mathrm{P}^{-}$ & Tanah, sekam dan pupuk kandang \\
$\mathrm{P} 1$ & 318 gram \\
$\mathrm{P} 2$ & 381 gram \\
$\mathrm{P} 3$ & 445 gram \\
$\mathrm{P} 4$ & 509 gram \\
\hline ngan pada perlakuan P0- dengan perbandingan 1:1
\end{tabular}

Keterangan pada perlakuan P0- dengan perbandingan 1:1 
Data hasil penelitian dianalisis menggunakan anava satu jalur adalah teknik statistik parametrik yang digunakan untuk menguji data bersekala interval atau rasio yang berasal dari satu variabel bebas (Winarsunu, 2015). Untuk mengetahui signifikasi pada setiap parameter pengamatan dilakukan dengan uji signifikansi pada rasio $F$. Jika $F_{e}>F_{t}$ maka diinterprestasikan signifikan yang berarti terdapat perbedaan, jika $F_{e}<F_{t}$ maka diinterprestasikan tidak signifikan yang berarti tidak terdapat perbedaan.

Apabila didapatkan data yang signifikan maka dilakukan uji lanjut berdasarkan perhitungan KK (koefesien keragaman) dengan rumus :

$$
\mathrm{KK}=\sqrt{\frac{R_{\text {galat }}}{\bar{y}}} \times 100 \%
$$

Dengan kriteria sebagai berikut :

1. Jika KK besar (minimal 10\% pada kondisi homogen atau minimal 20\% pada kondisi heterogen), uji lanjut yang dipakai yaitu uji Duncan.

2. Jika KK sedang (5-10\% pada kondisi homogen atau $10-20 \%$ pada kondisi heterogen), uji lanjut yang dipakai yaitu uji BNT (Beda Nyata Terkecil).

3. Jika KK kecil (maksimal 5\% pada kondisi homogen dan maksimal 10\% pada kondisi heterogen), uji lanjut yang dipakai yaitu BNJ (Beda Nyata Jujur) (Hanafiah, 2016).

\section{HASIL DAN PEMBAHASAN}

Setiap parameter pengamatan pada tomat ceri yang diteliti diperoleh dari pengukuran menggunakan alat seperti mistar benang dan timbangan . Perhitungan tinggi tanaman dan jumlah daun dilakukan pada tanaman tomat ceri yang telah berumur 3 minggu, 4 minggu, 5 minggu dan 6 minggu setelah tanam sedangkan pengukuran jumlah bunga diukur pada saat tomat ceri yang berumur 35, 38 dan 41 hari. Pada paremeter produktivitas jumlah buah dan berat buah dihitung pada setiap panen dari panen pertama sampai panen terakhir atau sampai buah habis dengan interval 3 hari sekali kemudian dijumlahkan di akhir panen.

Tabel 2. Data Rata-rata Pengukuran Satiap Parameter

\begin{tabular}{cccccc}
\hline Perlakuan & $\begin{array}{c}\text { Rata-rata Tinggi } \\
\text { Tanaman }( \pm) \\
\text { SD }\end{array}$ & $\begin{array}{c}\text { Rata-rata Jumlah } \\
\text { daun }( \pm) \text { SD }\end{array}$ & $\begin{array}{c}\text { Rata-rata } \\
\text { Jumlah Bunga } \\
( \pm) \text { SD }\end{array}$ & $\begin{array}{c}\text { Rata-rata Total } \\
\text { Jumlah Buah } \\
( \pm) \text { SD }\end{array}$ & $\begin{array}{c}\text { Rata-rata Total } \\
\text { Berat Buah }( \pm) \\
\text { SD }\end{array}$ \\
\hline $\mathrm{P}_{0}{ }^{-}$ & $95,35 \pm 8,91$ & $101 \pm 20,17(\mathrm{a})$ & $15,75 \pm 6,13$ & $16,5 \pm 4,2$ & $67,25 \pm 16,09(\mathrm{a})$ \\
$\mathrm{P}_{0^{+}}$ & $97,47 \pm 8,68$ & $119,75 \pm 11,15(\mathrm{~d})$ & $17 \pm 7,16$ & $16,5 \pm 6,03$ & $73,5 \pm 19,11(\mathrm{a})$ \\
$\mathrm{P}_{1}$ & $98,02 \pm 12,38$ & $90 \pm 12,84(\mathrm{a})$ & $18 \pm 7,07$ & $21,75 \pm 6,55$ & $86,75 \pm 26,89(\mathrm{a})$ \\
$\mathrm{P}_{2}$ & $103,3 \pm 10,43$ & $108,5 \pm 25,05(\mathrm{bc})$ & $22,75 \pm 8,99$ & $25,25 \pm 4,72$ & $106,5 \pm 21,74(\mathrm{~d})$ \\
$\mathrm{P}_{3}$ & $84,3 \pm 12,78$ & $93,75 \pm 7,79(\mathrm{a})$ & $17,75 \pm 10,59$ & $21,5 \pm 3,69$ & $96,75 \pm 26,6(\mathrm{bc})$ \\
$\mathrm{P}_{4}$ & $91,88 \pm 3,61$ & $81,75 \pm 9,20(\mathrm{a})$ & $16,5 \pm 3,10$ & $17,25 \pm 2,75$ & $67 \pm 23,36(\mathrm{a})$ \\
\hline
\end{tabular}

Penjelasan : Angka yang diikuti dengan huruf yang sama tidak berbeda nyata

Dari hasil pengkuran terhadap semua parameter pertumbuhan dan produktivitas didapatkan bahwa pupuk kompos limbah kulit nangka dengan metode takakura berpengaruh terhadap jumlah daun dan berat tanaman hal ini didapatakan dari uji anava satu jalur $\mathrm{Fe}>\mathrm{Ft}$ yang artinya $\mathrm{HO}$ ditolak dan Ha diterima, dan penggunaan pupuk kompos limbah kulit nangka dengan metode takakura tidak berpengaruh pada parameter tinggi tanaman, jumlah bunga dan jumlah buah hal ini 
didapatkan dari uji anava satu jalur didapatkan nilai nilai $\mathrm{Fe}<\mathrm{Ft}$. yang artinya $\mathrm{H} 0$ diterima dan Ha ditolak.

Dari setiap perlakuan yang diberikan memberikan hasil yang berbeda pada setiap parameter pengamatan. Dari parameter tinggi tanaman, jumlah bunga dan jumlah buah didapatkan hasil yang tidak signifikan atau tidak ada pengaruh pupuk kompos limbah kulit nangka dengan metode takakura terhadap tinggi tanaman, jumlah bunga dan jumlah buah tomat ceri. Dari setiap pengamatan didapatkan bahwa perlakuan P2 memberikan dampak yang paling baik jika dibandingkan dengan perlakuan lainnya, hal ini dikarenakan dengan interval waktu 2 minggu pada setiap pemupukan pupuk kompos dengan perlakuan P2 menjadi paling baik karena pupuk kompos dapat digunakan secara maksimal bagi tanaman tomat ceri, sedangkan pada perlakuan P1 pupuk kompos akan lebih cepat habis sebelum pemupukan berikutnya sedangkan pada perlakuan P3 dan P4 terjadi penumpukan kompos hal ini sesuai dengan penelitian Zabarti dkk (2010) bahwa penumpukan unsur hara akan berdampak terhambatnya pertumbuhan tanaman. Pada perlakuan P0- tanaman tomat ceri akan kehabisan unsur hara karena hanya mengandalkan media tanam sehingga kekurangan unsur hara akan menganggu pertumbuhan tanaman. Pada perlakuan $\mathrm{P} 0+$ pertumbuhan tanaman dan produktivitas tanaman akan berjalan baik namun penggunaan pupuk kimia secara terus menerus akan berdampak pada menurunnya kesuburan tanah sehingga produktivitas tanaman akan menurun (Isroi, 2009).

Faktor ekternal meliputi kondisi lingkungan yang tidak mendukung pertumbuhan tanaman, seperti suhu yang terlalu rendah atau tinggi, kekurangan dan kelebihan air dan kekurangan serta kelebihan unsur hara, dan pertumbuhan tanaman yang lambat bisa disebabkan oleh respon tanaman terhadap kekurangan air sedangkan pada faktor internal dapat disebabkan oleh gen atau varietas dari tanaman itu sendiri (Song \& Yunia. 2011) sehingga pemilihan benih yang baik akan berpengaruh pada pertumbuhan tanaman. Tanaman tomat memerlukan suhu yang optimal untuk menunjang masa vegetatifnya, pada masa ini suhu yang cocok untuk tanaman tomat ceri yaitu 24oC (Fitriani dkk, 2016) dengan suhu yang dapat ditolerir berikisar antara 25-30 oC, sedangkan pada pengamatan suhu di lingkungan penanaman bisa mencapai $26-30 \mathrm{oC}$ suhu yang terlalu tinggi dapat meningkatkan serangan hama pada tanaman tomat ceri yang akan menganggu pertumbuhan tanaman (Wahyuni dkk, 2018). Selain itu suhu yang terlalu tinggi dapat menyebabkan menurunya jumlah buah pertanaman karena proses pembuahan akan gagal (Hapsari dkk, 2017).

Pada paramater jumlah daun didiapatkan hasil yang signifikan artinya ada pengaruh pemberian pupuk kompos limbah kulit nangka dengan metode takakura terhadap jumlah daun dan berat buah tanaman tomat ceri. Kandungan unsur hara nitrogen didalam kulit nangka berfungsi sebagai pembentukan warna hijau daun yang membuat daun nampak lebih sehat (Bina Karya Tani, 2013). Daun merupakan salah satu organ tanaman yang memiliki fungsi yang sangat penting karena hampir semua fungsi yang lain tergantung pada kerja daun. Dari hasil fotosintesis yang dilakukan daun akan menghasilkan energi bagi tanaman, semakin banyak daun maka akan berpengaruh pada jumlah asimilat yang dihasilkan dan pada akhirnya akan berpengaruh pada pembentukan daun dan organ tanaman lainnya (Ohorella. 2011).

Masyarakat biasanya lebih menyukai buah tomat yang berukuran besar dengan warna kemerahan sehingga bobot buah merupakan bagian penting untuk melihat kualitas tomat, sehingga perlu diperhatikan kualitas dari varietas tomat dan bibit 
yang digunkanan (Hapsari dkk. 2017) untuk menjamin hasil produksi. Menurut Kurniawan dkk, (2014) kompos kulit nangka mengandung kandungan Kalium sebesar 0,61\%. Kandungan kalium berfungsi dalam meningkatkan kualitas buah sedangkan apabila tanaman kekurangan unsur kalium buah pada tanaman akan berukuran kecil-kecil, cepat rusak dan mudah membusuk (Tim Bina Karya Tani. 2013). Menurut Meylia (2018) bahwa unsur kalium merupakan unsur hara makro bagi tanaman yang dominan dibutuhkan tanaman pada masa generatif tanaman, karena kalium berfungsi dalam meningkatkan kualitas buah.

\section{SIMPULAN}

Berdasarkan hasil penetilian yang telah dilakukan dapat disimpulkan bahwa pupuk kompos limbah kulit nangka berperngaruh pada beberapa parameter pengamatan pada prtumbuhan dan produktivitas tanamana tomat ceri. Pupuk kompos limbah kulit nangka berperngaruh pada parameter pertumbuhan seperti pada paramater jumlah daun. Sedangkan pada parameter peroduktivitas pupuk kompos limbah kulit nangka dengan metode takakura berpengaruh pada parameter jumlah bunga dan berat buah pertanaman.

\section{REFERENSI}

Fitriani, H. P., \& Haryanti, S. (2016). Pengaruh Penggunaan Pupuk Nanosilika Terhadap Pertumbuhan Tanaman Tomat (Solanum lycopersicum) var.Bulat. Buletin Anatomi dan Fisiologi, 24 (1), 34-41.

Hapsari R., Didik I,. Ambarwati E. (2017). Pengaruh Pengurangan Jumlah Cabang dan Jumlah Buah Terhadap Pertumbuhan dan Hasil Tomat (Solanum lycopersicum L) Jurnal Vegetalika, 6 (3), 37-49.

Hidayah, A. (2017). Takakura Home Method; Solusi Cerdas Menciptakan Makassar Ta' Tidak Rantasa. Jurnal Penelitian dan Penalaran, 4 (2), 1-8.

Isroi \& Nurheti Yulirti. (2009). KOMPOS cara mudah, murah, da cepat menghasilkan kompos. Yogyakarta : C.V Andi Offset

Kurniawan, H. N.A., Kumalaningsih S., Febrianto A. M. (2014). Pengaruh Penambahan Konsentrasi Microbacter Alfaafa-11 (Ma-11) Dan Penambahan Urea Terhadap Kualitas Pupuk Kompos Dari Kombinasi Kulit Dan Jerami Nangka Dengan Kotoran Kelinci https://www.researchgate.net/publication/291354995 diakses tanggal 24-12-18.

Mauli, A. (2017). Dinas kebersihan kota lubuklinggau. http://klh.lubuklinggaukota.go.id/berita/sampah-masih-masalah-utama perkotaan/tanggal akses 24-12-18

Meylia, R. D \& Koesriharti. (2018). Pengaruh Pemberian Pupuk Fosfor Dan Kalium Yang Berbeda Terhadap Pertumbuhan Dan Hasil Tanaman Tomat (Lycopersicum esculantum Mill). Jurnal Produksi Tanaman, 6 (8), 1934-1941.

Ohorella, Zainudin. (2011). Respon Pertumbuhan dan Produktivitas Tanaman Kedelai Pada Sistem Olah Tanah yang Berbeda. Jurnal Agronomika, 1 (2), 92-98.

Song, N. A \& Banyo, Y. (2011). Konsentrasi Klorofil Daun Sebagai Indikator Kekurangan Air Pada Tanaman. Jurnal Ilmiah Sains, 11 (2), 166-174.

Supriati, Y \& Firmansyah D. Siregar. (2015). Bertanam tomat dalam pot. Jakarta : Penerbar Swadaya

Tim Bina Karya Tani. (2013). Pedoman Bertanam Tomat. Bandung: CV.Yrama Widya 
Wahyuni R., Sari I., \& Yusuf E Y. (2018). Pengaruh Pemberian Konsentrasi Terusi

$\left(\mathrm{CuSO}_{4}\right)$ Terhadap Produksi Tomat (Lycopersicum esculantum Mill) Pada Media Tanam Gambut. Jurnal Agro Indragiri, 1 (1), 244-254.

Warsidi, Edi. (2010). Mengelolah Sampah Menjadi Kompos. Bekasi: Mitra Utama

Winarsunu, T. (2015). Statistik dalam Penelitian Psikologi dan Pendidikan. Malang: UMM Press.

Zabarti E., Lestari W., \& Isda MN. (2010). Pengaruh Konsentrasi Dan Interval Waktu Pemberian Pupuk Organik Cair Nasa Terhadap Pertumbuhan Dan Produksi Tanaman Tomat (Solanum Lycopersicum Lam.). 1-10. http://repository.unri.ac.id. 